Original scientific paper

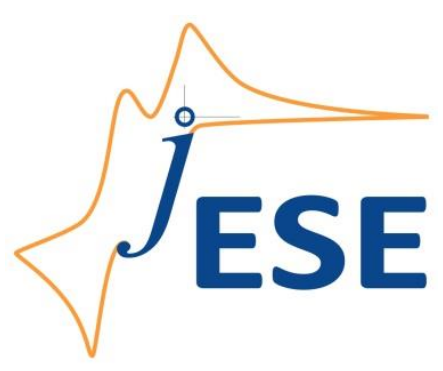

Open Access : : ISSN 1847-9286

www.jESE-online.org

\title{
Synthesis of CulnSe $e_{2}$ thin films from electrodeposited $\mathrm{Cu}_{11} \mathrm{In}_{9}$ precursors by two-step annealing
}

\author{
TSUNG-WEI CHANG, SHAO-YU HU, WEN-HSI LEE ${ }^{凶}$ \\ Department of Electrical Engineering, National Cheng Kung University, Tainan 701, Taiwan, R.O.C \\ Corresponding Authors: E-mail: leewen@mail.ncku.edu.tw
}

Received: February 12, 2013; Revised: November 22, 2013; Published: January 25, 2014

\begin{abstract}
In this study, copper indium selenide (CIS) films were synthesized from electrodeposited Cu-In-Se precursors by two-step annealing. The agglomeration phenomenon of the electrodeposited In layer usually occurred on the Cu surface. A thermal process was adopted to turn Cu-In precursors into uniform $\mathrm{Cu}_{11} \mathrm{In}_{9}$ binary compounds. After deposition of the Se layer, annealing was employed to form chalcopyrite CIS. However, synthesis of $\mathrm{CIS}$ from $\mathrm{Cu}_{11} \mathrm{In}_{9}$ requires sufficient thermal energy. Annealing temperature and time were investigated to grow high quality CIS film. Various electrodeposition conditions were investigated to achieve the proper atomic ratio of CIS. The properties of the CIS films were characterized by scanning electron microscopy (SEM), $X$-ray Diffraction (XRD), and Raman spectra.
\end{abstract}

\section{Keywords}

CulnSe $\mathrm{C}_{2} \mathrm{CIS}$, Annealing, Electrodeposition

\section{Introduction}

The solar cell has emerged as a very important non-conventional energy source. Copper indium selenide ( $\mathrm{CuInSe}_{2}$ ) is a I-III-VI group semiconductor compound offering good possibilities for thinfilm photovoltaic (PV) applications because it has a energy gap of $1.02 \mathrm{eV}$ [1-5]. Electrochemical deposition is a low cost method of producing thin CIS films because it has several advantages for large-area non-vacuum thin film production and little material waste. However, the crystallinity of CIS film grown by single-step electrodeposition is inferior because its growing temperature is much lower than that of the physical vapour deposition (PVD) method. The grains were small and loose. The CIS film can also be synthesized from co-sputtered $\mathrm{Cu}_{11} \mathrm{In}_{9}$-Se precursors by the thermal annealing process $[6,7]$. Large CIS grains can be grown due to the gas-liquid reaction during the annealing process [8]. The Cu-In alloys are usually co-sputtered by PVD. The PVD technology is 
excellent for good quality film growth but difficult to scale up because of the high manufacturing costs.

In this study, Cu-In precursors were prepared by multi-step electrodeposition. However, the agglomeration phenomenon of the electrodeposited In layer usually occurred on the Cu surface. The surface was non-uniform and discontinuous. An annealing process was adopted to transform $\mathrm{Cu}-\mathrm{In}$ to $\mathrm{Cu}_{11} \mathrm{In}_{9}$ compound and create a uniform surface structure. After deposition of the Se layer on the annealed $\mathrm{Cu}_{11} \mathrm{In}_{9}$, another annealing process is required to synthesize the CIS structure. Various annealing temperatures and times were adopted to investigate the proper annealing conditions and the mechanism of CIS synthesis. The deposition conditions were adjusted to achieve a better atomic ratio. The properties of the CIS films were characterized by scanning electron microscopy (SEM), X-ray Diffraction (XRD), and Raman spectra.

\section{Experiment}

The aqueous solution for the $\mathrm{Cu}$ deposition contained $0.75 \mathrm{MCuSO}_{4}, 4 \mathrm{mM} \mathrm{H}_{2} \mathrm{SO}_{4}$, and $0.5 \mathrm{mM} \mathrm{HCl}$. The aqueous solution for the Se deposition contained $17 \mathrm{mM} \mathrm{H}_{2} \mathrm{SeO}_{3}$ and $0.5 \mathrm{mM} \mathrm{HCl}$. The aqueous solution for the In deposition contained $50 \mathrm{mM} \mathrm{InCl}_{3}$ and $30 \mathrm{mM} \mathrm{HCl}$. The electrodepositions were carried out with AUTOLAB PGSTAT302, a conventional threeelectrode potentiostat, and the deposition conditions listed in Table 1. A thin slice of 99.99\% pure Pt electrode measuring $1 \times 4 \mathrm{~cm}$ was employed as the counter electrode, and an $\mathrm{Ag} / \mathrm{AgCl}$ electrode served as the reference electrode. Glass substrates with sputtered Mo film were used as the working electrodes. The electrodeposition area was a square measuring $1 \times 1 \mathrm{~cm}$. The substrates were cleaned by ultrasonication in acetone, $99.5 \%$ pure ethanol, and water before sputtering and electrodeposition. A magnetic stirrer was used for the stirring procedure. The rotation speed of the magnetic stirrer was set at $50 \mathrm{rpm}$.

Table 1. Electrodeposition and annealing condition of samples $a-f$.

\begin{tabular}{|c|c|c|c|c|c|}
\hline & \multirow{2}{*}{$\begin{array}{c}\mathrm{Cu} \\
i / \mathrm{mA}: \tau / \mathrm{s}\end{array}$} & \multirow{2}{*}{$\begin{array}{c}\ln \\
\tau / \mathrm{s}(i=5 \mathrm{~mA})\end{array}$} & \multicolumn{2}{|c|}{$\mathrm{Se}$} & \multirow{2}{*}{$\begin{array}{l}T_{\text {annealing }} /{ }^{\circ} \mathrm{C} \\
(\tau=5 \mathrm{~min})\end{array}$} \\
\hline & & & $i / \mathrm{mA}$ & $\tau / s$ & \\
\hline Sample a & $60: 20+20: 10$ & 350 & 4 & 1450 & 550 \\
\hline Sample b & $60: 20+20: 10$ & 350 & 4 & 1450 & 600 \\
\hline Sample c & $60: 20+20: 10$ & 350 & 4 & 1450 & 650 \\
\hline Sample d & $70: 20+20: 10$ & 350 & 4 & 1450 & 650 \\
\hline Sample e & $60: 10+30: 10$ & 375 & 4 & 1450 & 650 \\
\hline Sample f & $50: 10+20: 10$ & 350 & 4 & 1450 & 650 \\
\hline
\end{tabular}

The In deposition was carried out after the two-step growth of $\mathrm{Cu}$. The $\mathrm{Cu}$-In layers were treated by rapid thermal annealing (RTA) at $500{ }^{\circ} \mathrm{C}$ for $5 \mathrm{~min}$. The Se layer was deposited on the $\mathrm{Cu}$-In layer after annealing. The CIS film was synthesized by annealing the Cu-Se and In-Se precursors. The deposition conditions and RTA listed in Table 1 were found to achieve better proportions and structures.

The surface morphology and chemical composition of the films were characterized by SEM (Philips XL-40FEG) and EDS, respectively. The Raman spectra were produced with a backscattering configuration at room temperature with unpolarized light using a DILOR XY 800 spectrometer and 
an $\operatorname{Ar}$ laser with a $514.5 \mathrm{~nm}$ wavelength as the light source. The phase composition and the crystallographic structure were analysed by XRD using a Bruker D8 SSS multipurpose thin-film x-ray diffractometer.

\section{Results and discussion}

In this study, CulnSe $e_{2}$ thin films were synthesized from electrodeposited $\mathrm{Cu}$, In, and Se thin-film precursors. However, the electrodeposition of the In layer on the copper surface with a current of $60 \mathrm{~mA}$ in $20 \mathrm{~s}+20 \mathrm{~mA}$ in $10 \mathrm{~s}$ induced serious agglomeration phenomenon. Figure 1 shows the SEM image of the deposited In on the Cu layer. It was deposited with a current density of 3-6 $\mathrm{mA} \mathrm{cm}{ }^{-2}$. The agglomeration phenomenon made it difficult for the In layer to cover the whole surface. The grains of In were separated. Deposition with a high current density can lead to a better distribution of In. However, it also leads to large over potential, which would cause bubbles and a rough structure. A suitable value of $5 \mathrm{~mA}$ was employed for the deposition of In. After the deposition of Se, the Cu-In-Se precursor was annealed by RTA to form the CIS structure. The XRD results in Figure 2 show that the CIS structure can be synthesized at $450-550^{\circ} \mathrm{C}$. However, the SEM images in Figure 3 show that the film has a rough surface and a non-uniform grain size. The CIS structure came from the non-uniform In layer and the miscellaneous precursor type. The precursors not only contain $\mathrm{Cu}$, In and $\mathrm{Se}$, but also some binary compounds, including $\mathrm{Cu}_{11} \mathrm{In}_{9}$, $\mathrm{Cu}_{x} \mathrm{Se}$ and $\mathrm{In}_{2} \mathrm{Se}_{3}$, which were produced in the electrodeposition and annealing process. Different precursors have different reactions and temperature requirements to form $\mathrm{CIS}$, and other reactions lead to a uniform structure [9].

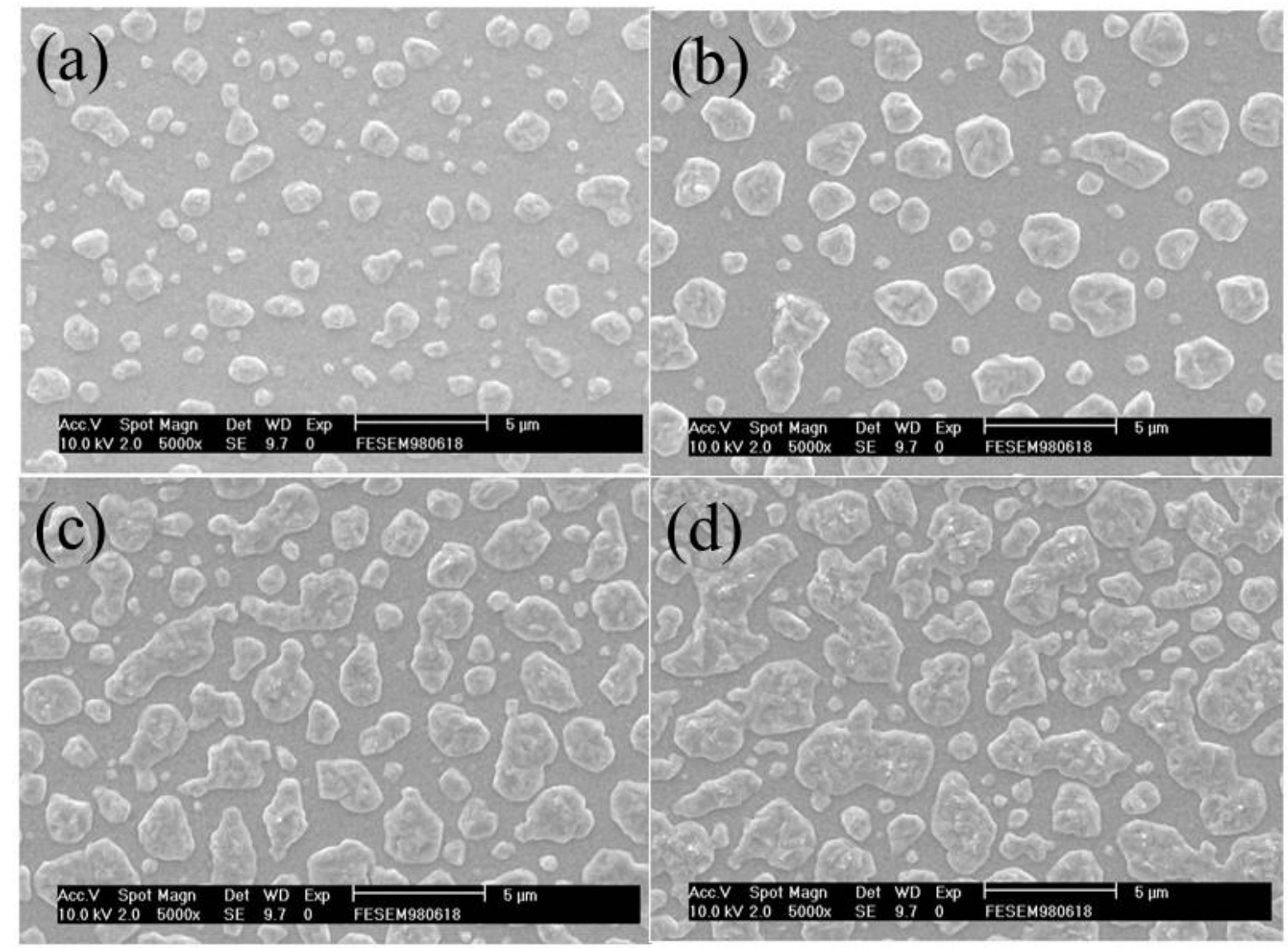

Fig. 1. SEM images of deposited In on Cu surface with current densities

(a) $3 \mathrm{~mA} \mathrm{~cm}^{-2}$ (b) $4 \mathrm{~mA} \mathrm{~cm}^{-2}$ (c) $5 \mathrm{~mA} \mathrm{~cm}$ (d) $6 \mathrm{~mA} \mathrm{~cm}^{-2}$ for $200 \mathrm{~s}$. 


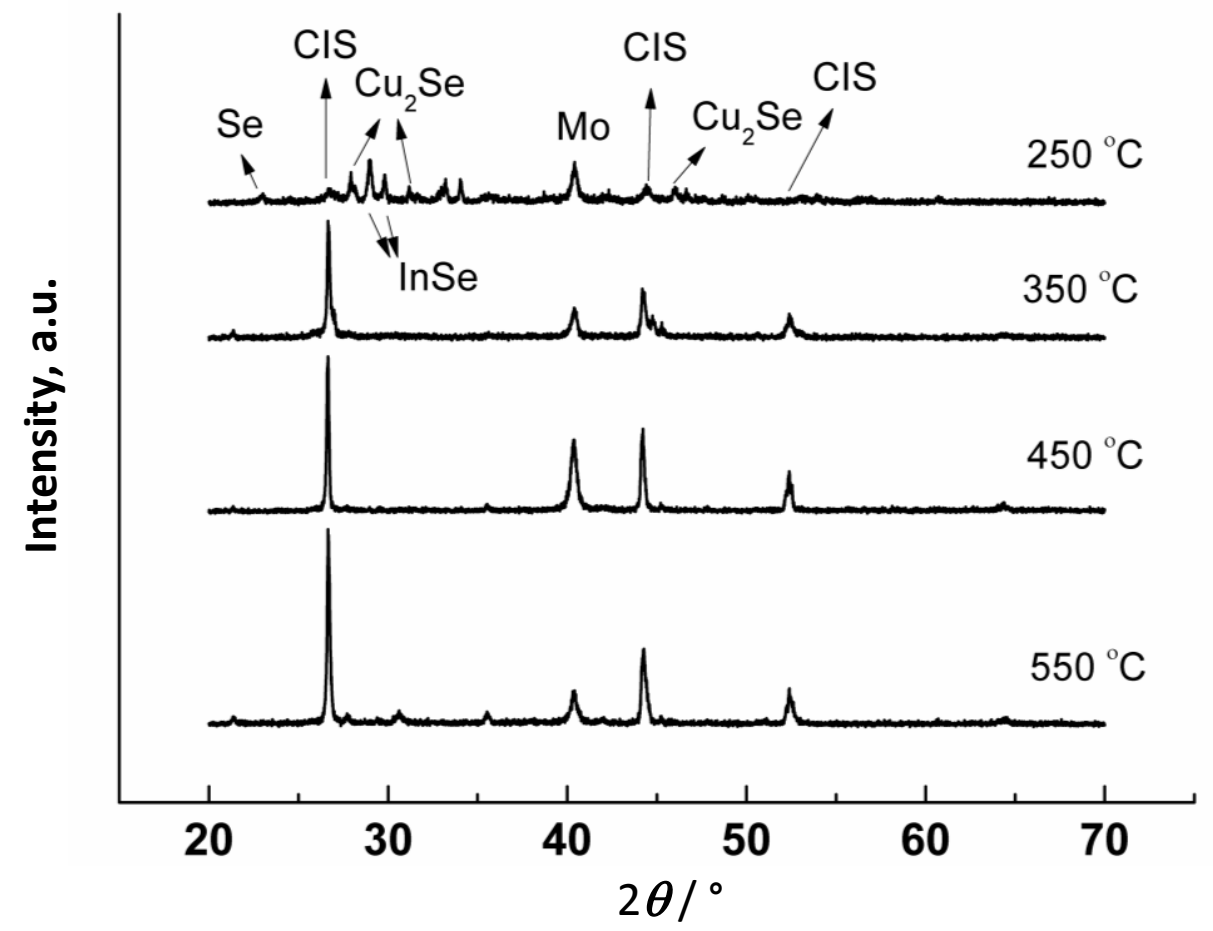

Fig. 2. XRD of annealed CIS film synthesized from Cu-In-Se precursor with temperature.

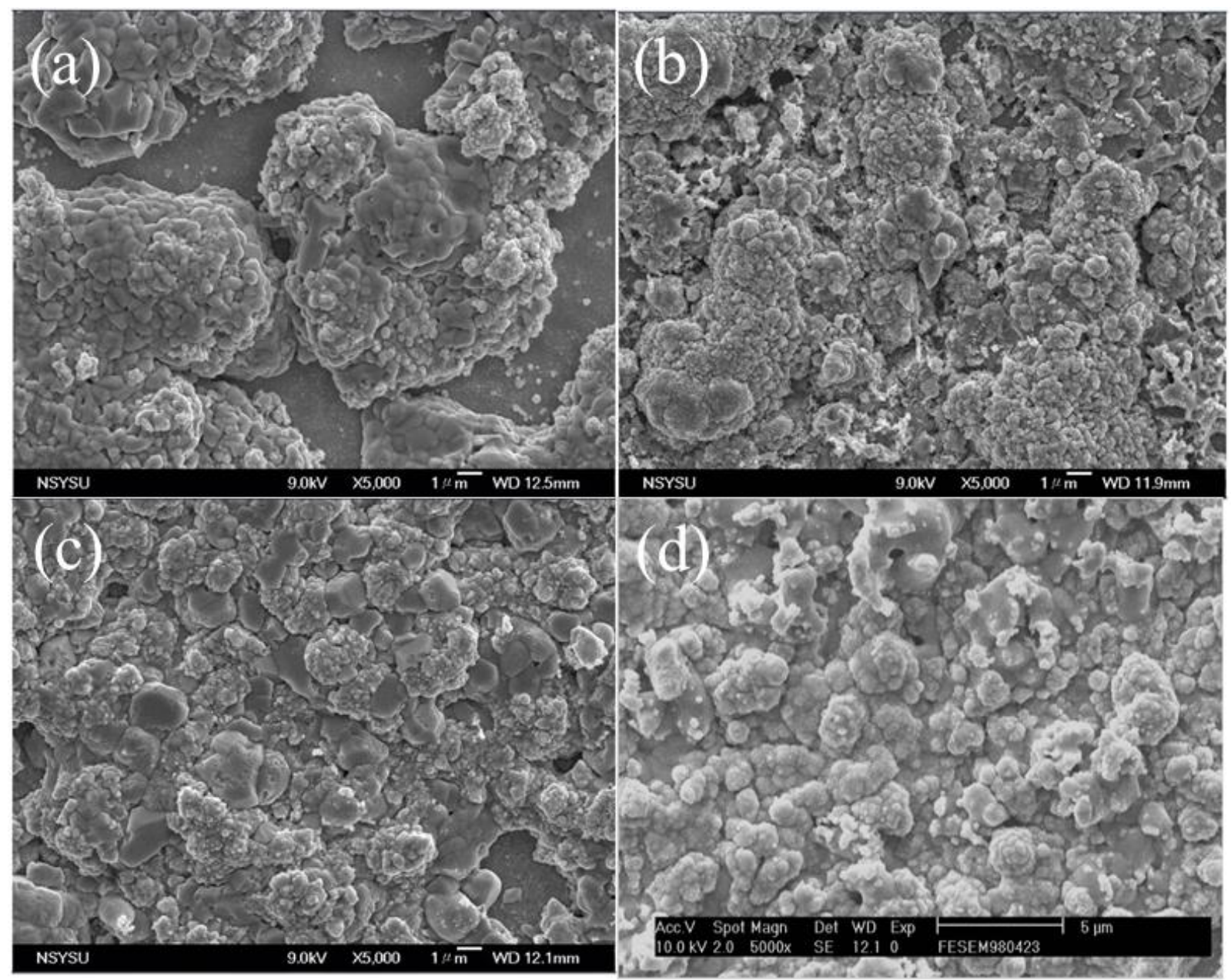

Fig. 3. SEM images of annealed CIS film synthesized from bilayer electrodeposition of Cu-In-Se precursors with temperature (a) $250^{\circ} \mathrm{C}$, (b) $350^{\circ} \mathrm{C},(\mathrm{c}) 450^{\circ} \mathrm{C}$, (d) $550^{\circ} \mathrm{C}$. 
In order to create a smooth In layer distribution and uniform CIS synthesis, a thermal pretreatment at $500{ }^{\circ} \mathrm{C}$ for $5 \mathrm{~min}$ was employed to improve the topography of the Cu-In layer. Figure 4 shows the SEM image of the $\mathrm{Cu}$-In thin film after annealing at $500{ }^{\circ} \mathrm{C}$ for $5 \mathrm{~min}$. The film re-grows continuously and covers the whole $\mathrm{Cu}$ surface. Figure 5 shows the XRD pattern of the annealed $\mathrm{Cu}$-In precursor. Most of the precursors were turned to $\mathrm{Cu}_{11} \mathrm{In}_{9}$ and small amounts to CulnSe . $^{2}$

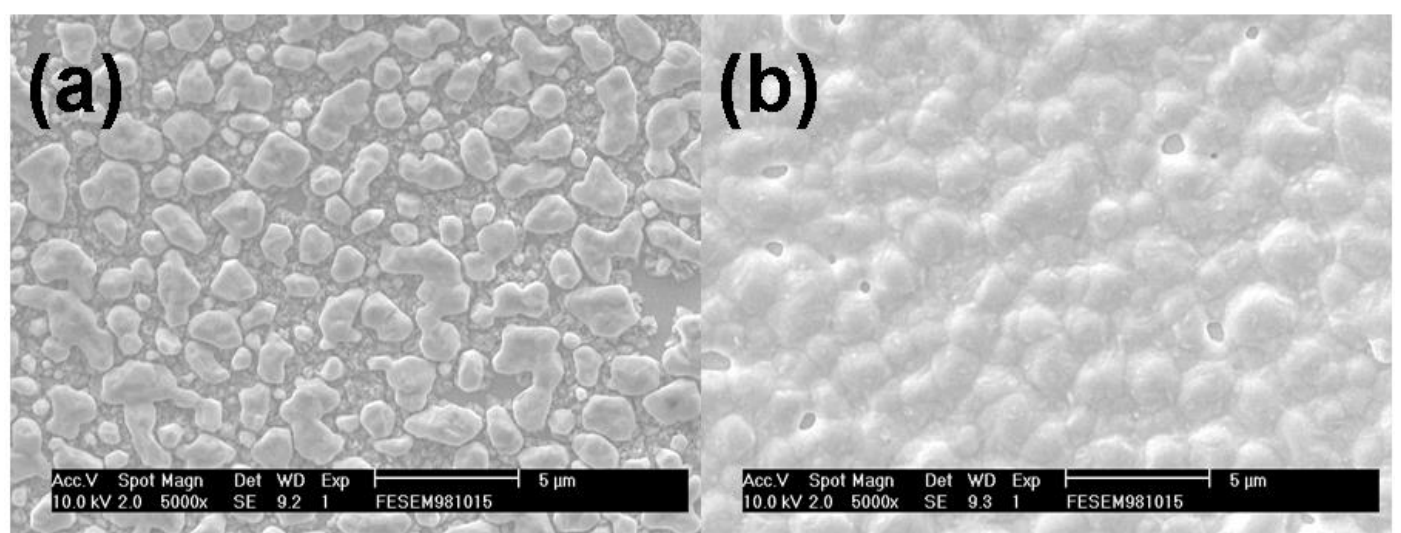

Fig. 4. SEM images of electrodeposited In layer on Cu surface (a) as-deposited film (b) annealed film.

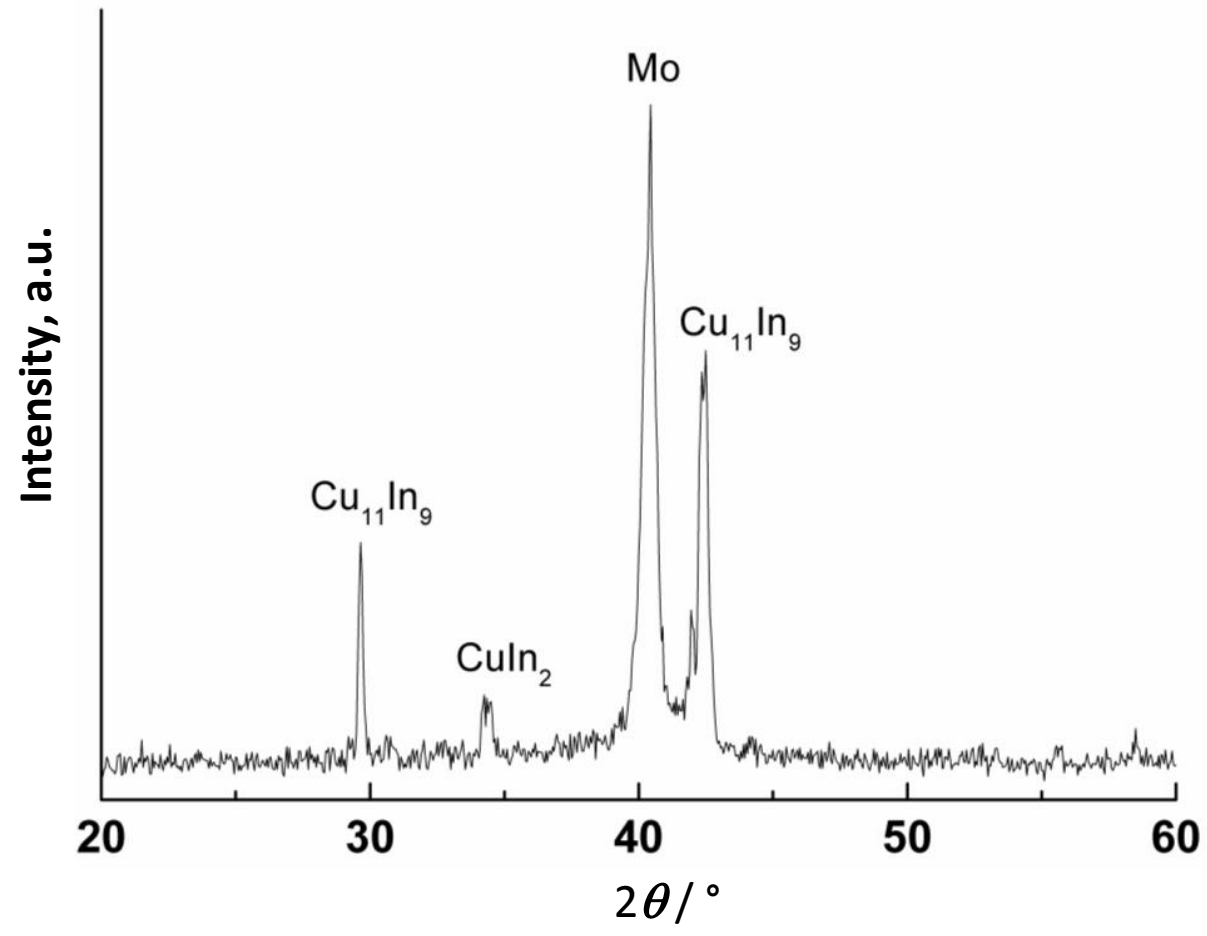

Fig.5. XRD pattern of annealed $\mathrm{CU} / \mathrm{In}$ precursors.

The Se layer was deposited on the annealed Cu-In surface at $4 \mathrm{~mA} \mathrm{~cm}{ }^{-2}$ current density for $1200 \mathrm{~s}$. All of the precursors were recrystallized by RTA at $600{ }^{\circ} \mathrm{C}$ for $3 \mathrm{~min}$ and observed by SEM and EDS. Figure $6(\mathrm{a})$ shows the microstructure of the annealed $\mathrm{CIS}$ film at $600{ }^{\circ} \mathrm{C}$ for $3 \mathrm{~min}$. The grain size of the annealed CIS film synthesized from $\mathrm{Cu}_{11} \mathrm{In}_{9}$-Se precursors is much larger than that of CIS film annealed by co-electrodeposition. During the thermal annealing, the Cu-In became liquid phase and reacted with the gas phase Se. CIS grain growing and diffusion were easier in the gas-liquid reaction. However, many voids were observed in the SEM image. This was because CIS synthesis from the reaction of $\mathrm{Cu}_{11} \mathrm{In}_{9}$-Se precursors requires a higher annealing temperature. 
Figure $6(\mathrm{~b})$ shows the microstructure of the $\mathrm{CIS}$ film with an annealing temperature of $630{ }^{\circ} \mathrm{C}$ for $3 \mathrm{~min}$. A higher synthesis temperature certainly reduces the voids in the film.

However, the EDS results shown in Table 2 indicate that the composition of the film is not optimum for CIS. Se gas would easily dissipate during annealing. In Samples a, b, and c listed in Table 1, the deposition times of Se was increased to $1450 \mathrm{~s}$ and the annealing temperature was adjusted to find the proper value. The EDS results shown in Table 2 indicate that the atomic ratio of Se increases to an appropriate value of $50 \%$.

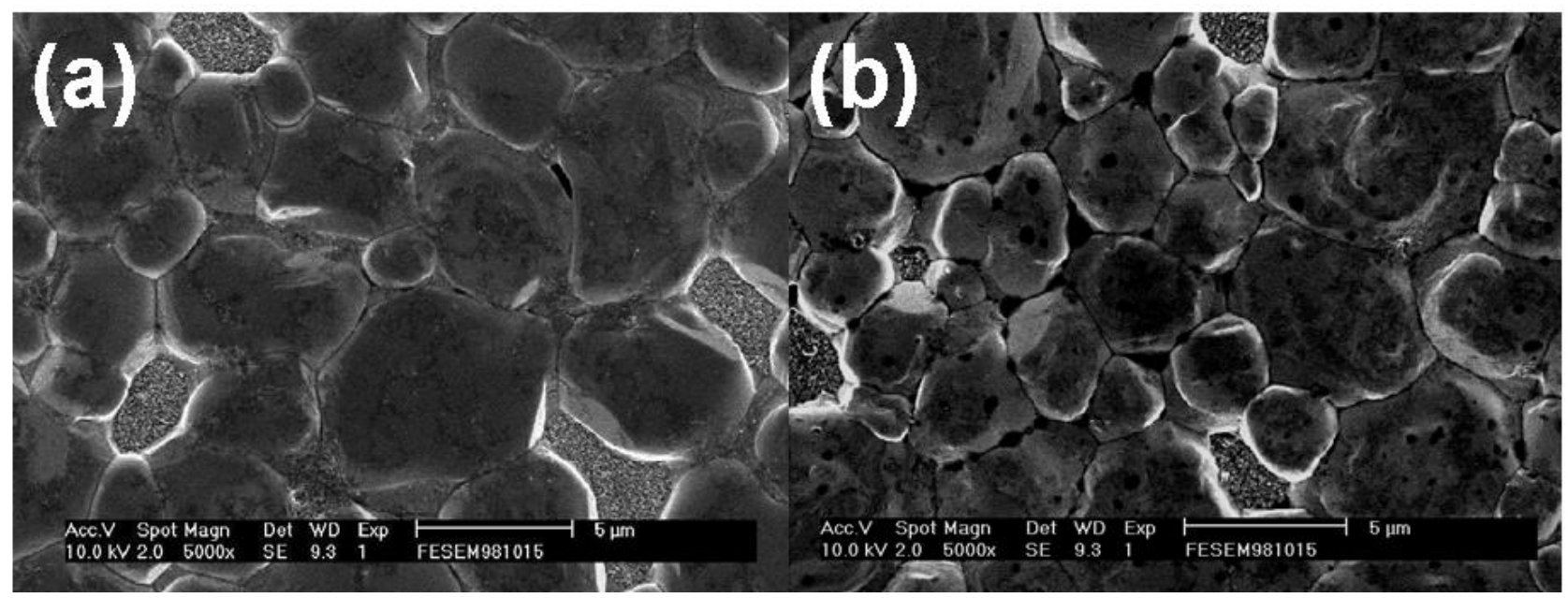

Fig. 6. SEM images of CIS film after annealing at (a) $600^{\circ} \mathrm{C}$, (b) $630^{\circ} \mathrm{C}$ for $3 \mathrm{~min}$.

Table 2. The EDS analysis of atomic percent of CIS film after increasing the deposition time for $1200 \mathrm{~s}$ and 1450 s of Se

\begin{tabular}{ccccc}
\hline at. \% of $\mathrm{Cu}$ & at. \% of $\mathrm{In}$ & at. \% of $\mathrm{Se}$ & $\mathrm{Cu} / \mathrm{In}$ ratio & Se deposition time, $\mathrm{s}$ \\
\hline 29.1 & 24.7 & 46.2 & 1.17 & 1200 \\
26.6 & 23.2 & 50.2 & 1.14 & 1450 \\
\hline
\end{tabular}

Figure 7 shows the SEM images of Samples a, b, and c. It is observed that increasing the annealing temperature can increase the grain size of the CIS film. The voids on the surface were also reduced with the higher temperature. A higher annealing temperature could provide sufficient energy for the CIS film to diffuse and react more completely. The deposition condition was adjusted in Samples d, e, and $f$ to achieve a proper $\mathrm{Cu}$-In ratio. The EDS results are shown in Table 3. The Cu-In ratio of Sample f achieved nearly 1:1.

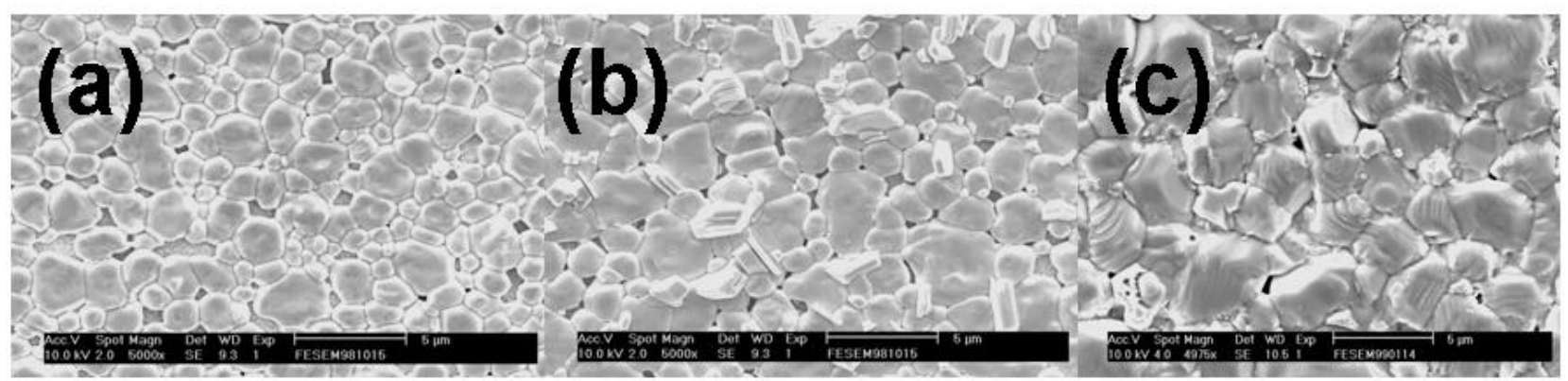

Fig. 7. SEM images of CIS film with the Se layer deposited on the annealed $\mathrm{CU} / \mathrm{In}$ surface at $4 \mathrm{~mA} \mathrm{~cm}^{-2}$ current density for $1200 \mathrm{~s}$ after annealing at (a) $600^{\circ} \mathrm{C}$ (b) $630^{\circ} \mathrm{C}$ for $3 \mathrm{~min}$. 
Table 3. The EDS analysis of atomic percent in samples $d, e$, and $f$.

\begin{tabular}{lcccc}
\hline & at. \% of $\mathrm{Cu}$ & at. \% of In & at. \% of Se & Cu/In ratio \\
\hline Sample d & 25.6 & 24.3 & 50.1 & 1.05 \\
Sample e & 25.4 & 22.8 & 51.8 & 1.11 \\
Sample $\mathrm{f}$ & 24.9 & 24.5 & 50.6 & 1.01 \\
\hline
\end{tabular}

Figure 8 shows the SEM images of Sample $f$ after annealing at $630{ }^{\circ} \mathrm{C}$ for $5 \mathrm{~min}$ and $10 \mathrm{~min}$. The grain of CIS film became large and dense, and the voids almost disappear in Sample $f$. The crosssection images of Sample $f$ are shown in Figure 9. Large dense grains could be clearly observed and the thickness of the CIS approached $2 \mu \mathrm{m}$.

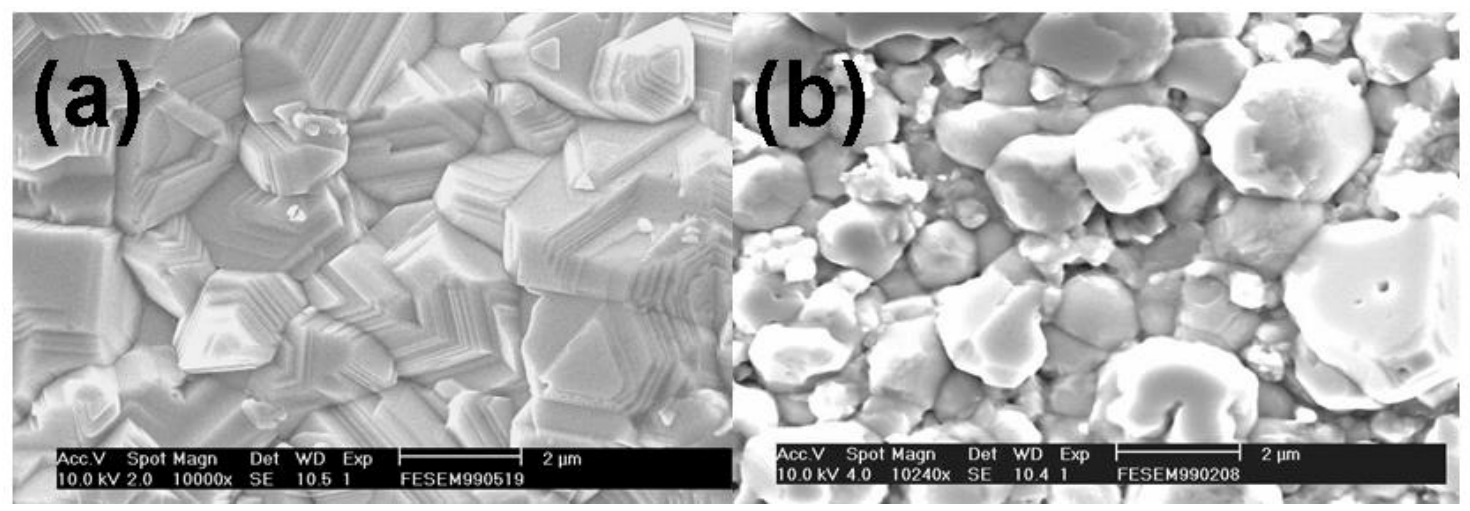

Fig. 8. SEM images of sample $f$, annealed at $630{ }^{\circ} \mathrm{C}$ for (a) $5 \mathrm{~min}$ (b) $10 \mathrm{~min}$.

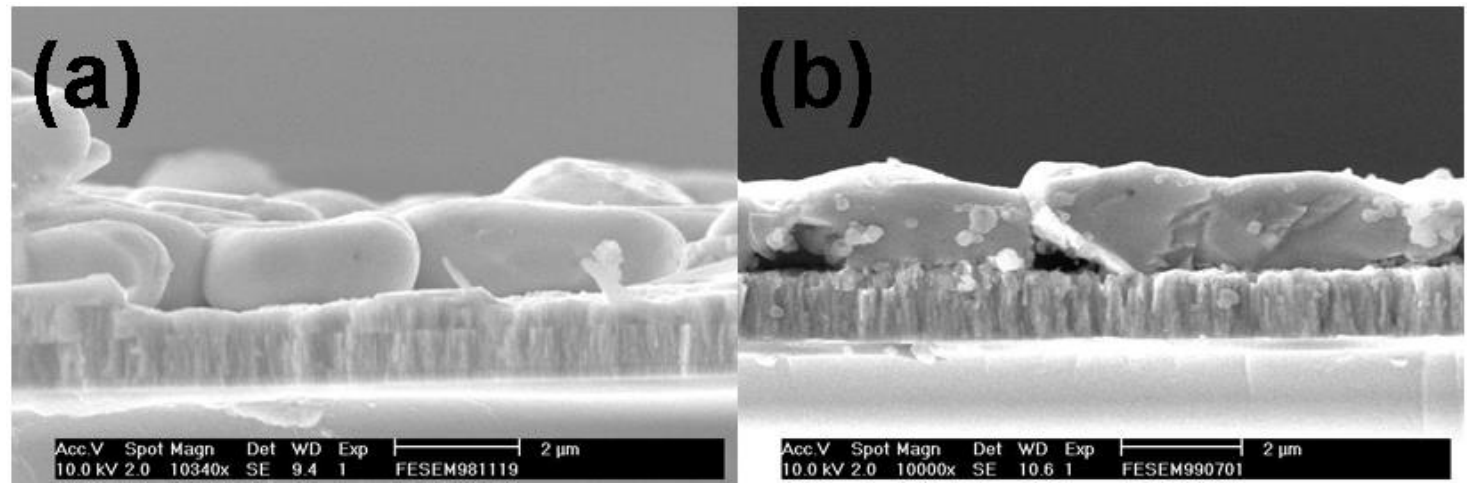

Fig. 9. SEM images of cross-section of sample $f$, annealed at $630^{\circ} \mathrm{C}$ for (a) $5 \mathrm{~min}$, (b) $10 \mathrm{~min}$.

Figure 10 shows the XRD patterns of the CIS films with various annealing conditions. The main (112) peak confirmed the existence of chalcopyrite CIS. The (112) main peaks of the CIS films annealed at $550{ }^{\circ} \mathrm{C}$ for $5 \mathrm{~min}$ and at $600{ }^{\circ} \mathrm{C}$ for 5 min contained some small peaks of impure phase. However, the peaks were too close to be differentiated clearly by XRD, but the Raman analysis found $\mathrm{Cu}_{1-\mathrm{x}} \mathrm{Se}_{\mathrm{x}}$ or $\mathrm{In}_{\mathrm{x}} \mathrm{Se}$.

A Raman spectrum was employed to analyse the film composition. Figure 11 shows the Raman spectra of the CIS films with various annealing conditions. $\mathrm{Cu}_{2} \mathrm{Se}$ was found in the samples with the lower annealing temperature or shorter annealing time. This is because $\mathrm{Cu}_{2} \mathrm{Se}$ was formed before the synthesis of CIS. If the annealing does not provide sufficient energy or reaction time, the precursors cannot completely transform to CIS. Figure 12 shows the XRD patterns of the CIS film with the lower annealing temperature. Cu-Se and In-Se were found at $300{ }^{\circ} \mathrm{C}$ and $\mathrm{CIS}$ (112) was found at $350^{\circ} \mathrm{C}$. This indicates that the precursors would turn into Cu-Se and In-Se binary compounds before the synthesis of the chalcopyrite CIS [10]. 

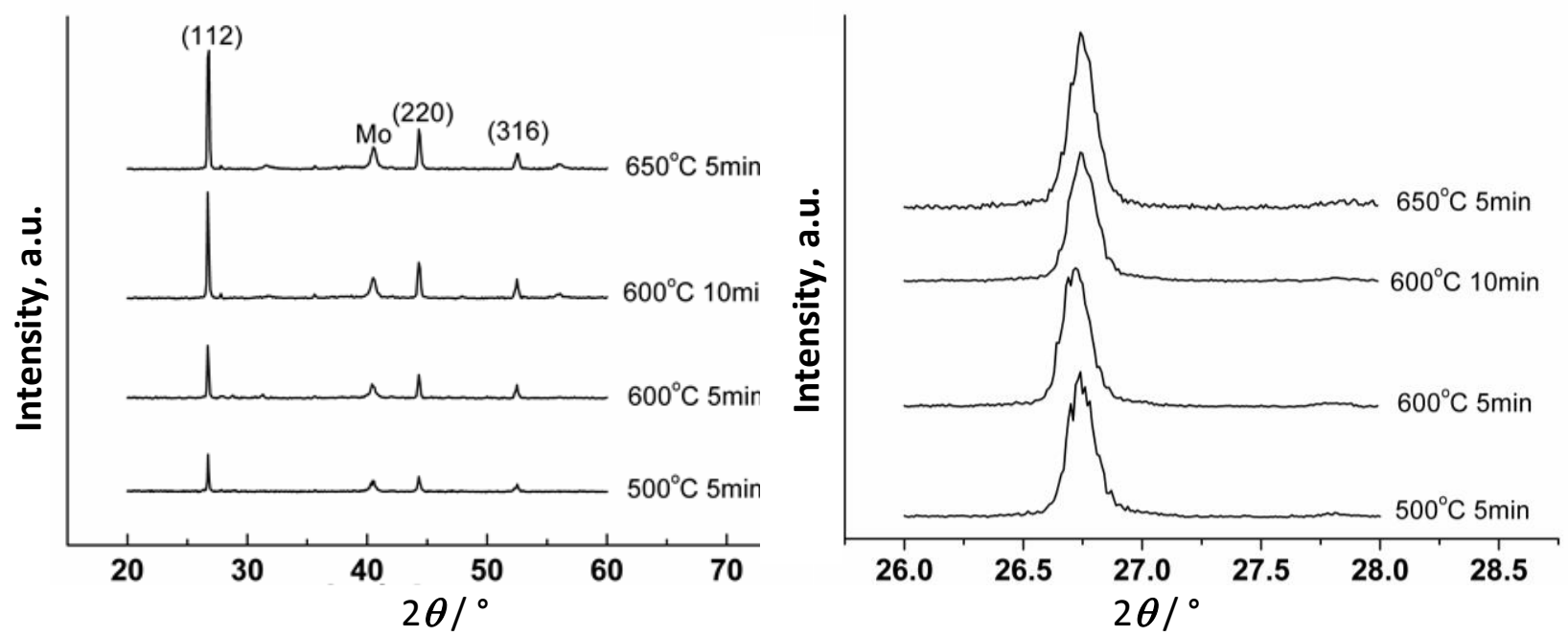

Fig.10. XRD patterns of CIS films with conditions.

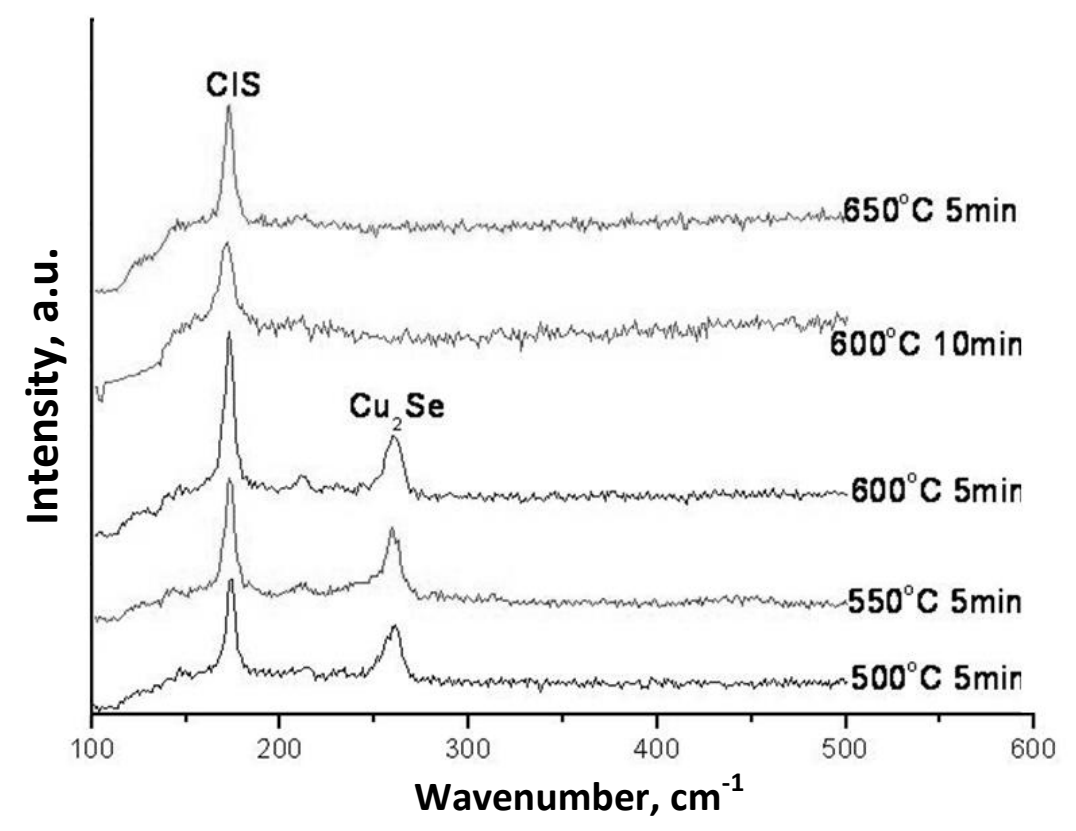

Fig.11. Raman spectra of CIS films obtained with conditions.

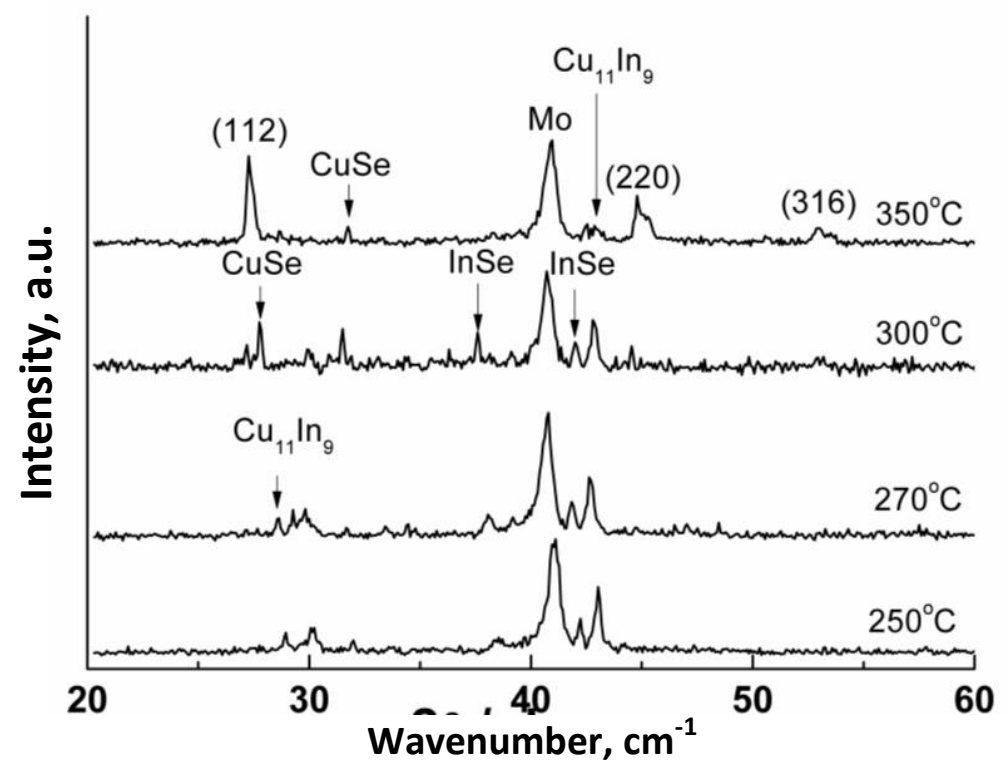

Fig.12. XRD patterns of CIS films after annealing at low temperature $250^{\circ} \mathrm{C} 350^{\circ} \mathrm{C}$. 
However, synthesized $\mathrm{CIS}$ from co-sputtered $\mathrm{Cu}_{11} \mathrm{In}_{9}$ can produce high quality film with large grains. In this study, synthesis of the CIS from the electrodeposited Cu-In precursors was investigated. A thermal process was adopted to eliminate the agglomeration phenomenon of electrodeposited $\mathrm{In}$ and to form $\mathrm{Cu}_{11} / \mathrm{n}_{9}$ compound. The electrodeposition conditions of $\mathrm{Cu}, \mathrm{In}$ and Se, were adjusted to achieve the preferred atomic proportion. However, the annealing temperature of the synthesized $\mathrm{ClS}$ from $\mathrm{Cu}_{11} \mathrm{In}_{9}$ is critical. The XRD patterns and Raman spectra show that the residue of the $\mathrm{Cu}_{2} \mathrm{Se}$ compound is due to an incomplete reaction at lower annealing temperatures. Large dense grains could be grown at $650{ }^{\circ} \mathrm{C}$ for 5 min. Finally, we produced a high quality CIS film with large grains from a cheap method of electrodeposition of Cu-In precursors.

\section{Conclusions}

Electrodeposition is a cheap and efficient method of producing CIS film. The crystallinity of the co-electrodeposited film is inferior because of the low growing temperature. Synthesizing CIS from co-sputtered $\mathrm{Cu}_{11} \mathrm{In}_{9}$ can produce high quality film with large grains. In this study, synthesizing CIS from electrodeposited $\mathrm{Cu}$-In precursors was investigated. A thermal process was adopted to eliminate the agglomeration phenomenon of electrodeposited In to form $\mathrm{Cu}_{11} \mathrm{In}_{9}$ compound. The electrodeposition conditions of $\mathrm{Cu}, \mathrm{In}$ and $\mathrm{Se}$, were adjusted to achieve the preferred atomic proportion. However, the annealing temperature of synthesized $\mathrm{ClS}$ from $\mathrm{Cu}_{11} \mathrm{In}_{9}$ is critical. The XRD patterns and Raman spectra show that the $\mathrm{Cu}_{2} \mathrm{Se}$ compound residue is due to an incomplete reaction at lower annealing temperatures. Large dense grains could be grown at $650^{\circ} \mathrm{C}$ for $5 \mathrm{~min}$.

\section{References}

[1] K. Siemer, J. Klaer, I. Luck, J. Bruns, R. Klenk, D. Bräunig, Sol. Energy Mater. Sol. Cells 67 (2001) 159.

[2] J. Klaer, I. Luck, A. Boden, R. Klenk, I. Gavilanes Perez, R. Scheer, Thin Solid Films 432 (2003) 534.

[3] D. Lincot, J. F. Guillemoles, S. Taunier, D. Guimard, J. Sicx-Kurdi, A. Chaumont, O. Roussel, O. Ramdani, C. Hubert, J. P. Fauvarque, Sol. Energy 77 (2004) 725.

[4] R. N. Bhattacharya, J. F. Hiltner, W. Batchelor, M. A. Contreras, R. N. Noufi, J. R. Sites, Thin Solid Films 361 (2000) 396.

[5] K. Singh, R. Tanveer, Sol. Energy Mater. Sol. Cells 36 (1995) 409.

[6] F.O. Adurodija, J. Song, S.D. Kim, S.H. Kwon, S.K. Kim, S.H. Yoon and B.T. Ahn, Thin Solid Films 338 (1999) 13.

[7] F. Adurodija, J. Song, S. K. Kim, K. H. Kang and K. H. Yoon, Journal of the Korean Physical Society 32 (1998) 87.

[8] T. L. Chu, Shirley S. Chu, J. Yue, Solid-State Science and Technology 131 (1984) 2182-2185.

[9] O. Volobujeva, M. Altosaar, J. Raudojaa, E .Mellikov, M. Grossberg, L. Kaupmees, P. Barvinschi, Solar Energy Materials \& Solar Cells 93 (2009) 11.

[10] S. D. Kim and H. J. Kim, Journal of the Korean Physical Society 35 (1999) 403.

(C) 2014 by the authors; licensee IAPC, Zagreb, Croatia. This article is an open-access article distributed under the terms and conditions of the Creative Commons Attribution license (http://creativecommons.org/licenses/by/3.0/) (cc) EY 